\title{
Occurrence and new data of dellaite from the Akagane mine, Japan
}

\author{
Hidehiko SHIMAZAKI ${ }^{* * *}$, Ritsuro MIYAWAKI ${ }^{*}$, Kazumi YoKOYAMA*, \\ Satoshi Matsubara* and Michiaki BunNo*** \\ *Department of Geology and Paleontology, National Museum of Nature and Science, \\ Hyakunin-cho, Shinjuku, Tokyo 169-0073, Japan \\ ${ }^{* *}$ University of Tokyo, Hongo, Bunkyo, Tokyo 113-0033, Japan \\ ${ }^{* * *}$ Geological Museum, Geological Survey of Japan, AIST, \\ 1-1-1 Higashi, Tsukuba 305-8567, Japan
}

\begin{abstract}
A new occurrence of dellaite, a very rare mineral, at the Akagane mine, Japan, was confirmed and its chemical composition and XRD data for the natural material are reported for the first time in this paper. The mineral occurs in the high-temperature skarn of bicchulite and vesuvianite as a veinlet or interstitial constituent. Results of electron microprobe analysis indicated that the chemical composition of dellaite is almost identical to $\mathrm{Ca}_{6} \mathrm{Si}_{3}$ $\mathrm{O}_{11}(\mathrm{OH})_{2}$, and only a small amount of chlorine substitutes $(\mathrm{OH})$. The six strongest lines in the powder XRD pattern are as follows: 3.07 (53) 0-22, 2.99 (38) 022, 2.86 (44) -2-11, 2.82 (100) 20-3, 2.55 (51) 005, and 2.29 (38) 030. The lattice parameters refined from the powder XRD data are as follows: $a=6.815(4), b=6.937(3)$, and $c$ $=12.890(6) \AA ; \alpha=90.71(4), \beta=97.68(4), \gamma=98.20(4)^{\circ}$, and $V=597.4(5) \AA^{3}$. The indices are $\alpha=1.655$ and $\gamma$ $=1.664$, and optically biaxial; negative with $2 \mathrm{~V}=$ large $\left(>70^{\circ}\right)$. Dellaite appears to be a later-stage hydration product of pre-existing skarn mineral(s) under a silica-deficient environment.
\end{abstract}

Keywords: Dellaite, Hydrous dicalcium silicate, Skarn, Akagane mine

\section{INTRODUCTION}

Dellaite is a very rare hydrous dicalcium silicate, $\mathrm{Ca}_{6}\left(\mathrm{Si}_{2} \mathrm{O}_{7}\right)\left(\mathrm{SiO}_{4}\right)(\mathrm{OH})_{2}$ or $3\left(\mathrm{Ca}_{2} \mathrm{SiO}_{4}\right) \cdot \mathrm{H}_{2} \mathrm{O}$, which was first discovered by Agrell (1965) at Kilchoan, Scotland, in polythermally metamorphosed limestone. Its synthetic equivalent has been studied as a major calcium silicate hydrate phase $\left(\gamma-\mathrm{C}_{6} \mathrm{~S}_{3} \mathrm{H}\right.$ in the $\mathrm{C}-\mathrm{S}-\mathrm{H}$ system $)$ in the cement industry engineering. Agrell (1965) found that the $\mathrm{X}$-ray oscillation photograph of a single crystal of this mineral extracted from a thin section was identical to that of the phase Y synthesized by Roy (1958), whose formula, $\mathrm{Ca}_{6} \mathrm{Si}_{3} \mathrm{O}_{11}(\mathrm{OH})_{2}$, was determined by Glasser and Roy (1959). Safronov et al. (1981) refined the crystal structure of the phase $\mathrm{Y}$ and verified that the structural formula of the synthetic equivalent of dellaite is $\mathrm{Ca}_{6}\left(\mathrm{Si}_{2} \mathrm{O}_{7}\right)\left(\mathrm{SiO}_{4}\right)$ $(\mathrm{OH})_{2}$. However, only very limited mineralogical data are available on this mineral; even chemical and $\mathrm{X}$-ray powder diffraction data on this natural material have not yet been reported. As far as the present authors know, since

doi:10.2465/jmps.080214

H. Shimazaki, caw40120@pop21.odn.ne.jp Corresponding author the first discovery by Agrell (1965), no systematic description of this mineral has been published, although some information suggests that the mineral occurs elsewhere (e.g., Queretaro, Mexico, with rustumite; Excalibur Mineral Corporation, 2005).

In the process of a mineralogical study of high-temperature skarn from the Akagane mine, Iwate Prefecture, Japan, Bunno et al. (1982) found an undetermined mineral with a Ca:Si ratio of 2:1. This mineral is confirmed in the present study to be dellaite. In this study, we report the occurrence and some chemical and physical data of dellaite from the Akagane mine.

\section{OCCURRENCE}

The Akagane mine is located in the Kitakami Mountains, Northeast Japan (Fig. 1), and comprises several $\mathrm{Fe}-\mathrm{Cu}$ ore deposits formed by early Cretaceous igneous activities (Ishiyama, 2005). In addition to such ore-bearing skarns, barren high-temperature skarns are formed along the contact zone between gabbro and limestone in the Sakae deposit of the mine. A detailed description of skarns formed 


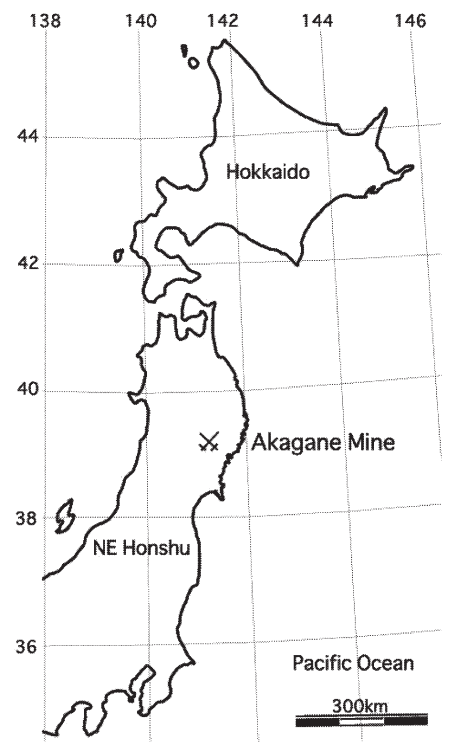

Figure 1. Index map showing the locality of the Akagane mine, Northeast Japan.

Table 1. Analytical results of dellaite

\begin{tabular}{|c|c|c|c|c|}
\hline & Range & Average & S.D. $(\sigma)$ & Ideal* \\
\hline $\mathrm{SiO}_{2}(\mathrm{wt} \%)$ & $33.1-34.2$ & 33.7 & 0.306 & 33.71 \\
\hline $\mathrm{CaO}$ & $61.6-62.8$ & 62.4 & 0.366 & 62.92 \\
\hline $\mathrm{Cl}$ & 0.2 & 0.2 & 0 & \\
\hline $\mathrm{Cl}_{2}=\mathrm{O}$ & $(-) 0.0$ & & & \\
\hline$\left(\mathrm{H}_{2} \mathrm{O}\right)^{* *}$ & $3.2-4.6$ & 3.7 & 0.445 & 3.37 \\
\hline Total & 100 & 100 & & 100 \\
\hline \multicolumn{5}{|c|}{ Number of atoms on the basis of $\left(\mathrm{O}+{ }^{1} / 2 \mathrm{Cl}\right)=13$} \\
\hline \multicolumn{2}{|l|}{$\mathrm{Si}$} & \multicolumn{2}{|l|}{2.99} & 3 \\
\hline \multicolumn{2}{|l|}{$\mathrm{Ca}$} & \multicolumn{2}{|l|}{5.93} & 6 \\
\hline \multicolumn{2}{|l|}{$\mathrm{Cl}$} & \multicolumn{2}{|l|}{0.03} & 0 \\
\hline \multicolumn{2}{|l|}{$\mathrm{H}$} & \multicolumn{2}{|l|}{2.19} & 2 \\
\hline \multicolumn{5}{|c|}{$\mathrm{Ca}_{5.93} \mathrm{Si}_{2.99} \mathrm{O}_{10.82}(\mathrm{OH})_{2.19} \mathrm{Cl}_{0.03}$} \\
\hline
\end{tabular}

* Ideal composition of dellaite $\mathrm{Ca}_{6} \mathrm{Si}_{3} \mathrm{O}_{11}(\mathrm{OH})_{2}$.

** Obtained by subtracting the total $\mathrm{wt} \%$ of detected constituents from 100 .

along this contact zone was given by Bunno et al. (1982). Dellaite occurs in the skarn of bicchulite and vesuvianite, one of the typical high-temperature skarns along the contact zone, as a veinlet (Figs. 2A and 2B) or an interstitial constituent (Fig. 2C), making aggregates of short prismatic to irregular-shaped grains intimately associated with calcite and clintonite. The veinlet of dellaite is white, and reaches $2 \mathrm{~mm}$ in width. Granular vesuvianite of about 0.1 $\mathrm{mm}$ in diameter is scattered in a network matrix of bicchulite, and when dellaite occurs interstitially, it appears poikilitic, since it includes many small vesuvianite granules. Apart from these minerals, the skarn contains small amounts of magnetite and sphalerite.
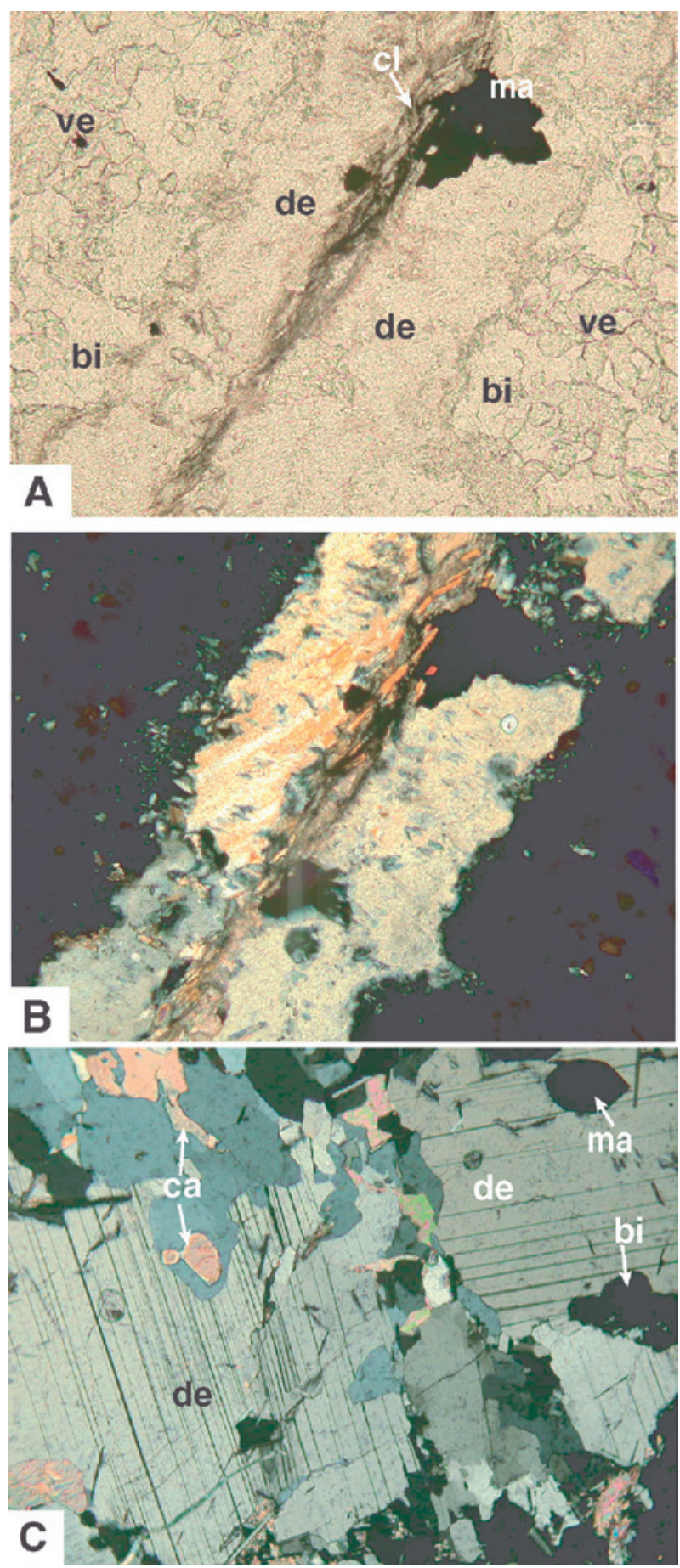

Figure 2. Photomicrographs of dellaite. The width of each photograph is about $1.6 \mathrm{~mm}$. (A) and (B) Veinlet of dellaite (de) aggregate cutting bicchulite (bi) - vesuvianite (ve) skarn, with clintonite (cl) and magnetite (ma). (C) Aggregate of dellaite exhibiting polysynthetic twinning, with minor calcite (ca), magnetite, and bicchulite. (A) - Open polar; (B) and (C) - Crossed polars. 


\section{CHEMICAL COMPOSITION}

The chemical composition of dellaite was determined by electron micro-probe analyses. The range and average $\mathrm{wt} \%$ of the constituents determined from seven representative analyses are shown in Table 1 . A preliminary study of the mineral was carried out for qualitative and semiquantitative analysis using an electron microscope equipped with an energy dispersive spectrometer (JEOL 5400 with fully quantitative Link Systems model QX2000) at the National Museum of Nature and Science, by employing an operating voltage of $15 \mathrm{kV}$ and a Faraday cup current of $1 \mathrm{nA}$. Quantitative analysis was subsequently performed using an electron-probe microanalyzer equipped with a wave length spectrometer (JEOL JXA 8800) at the National Museum of Nature and Science, by employing an operating voltage of $15 \mathrm{kV}$ and a current of $20 \mathrm{nA}$, with a beam diameter of about $2 \mu \mathrm{m}$. The following materials were used as standards: synthetic $\mathrm{CaSiO}_{3}$ for $\mathrm{Si}$ and $\mathrm{Ca}$, and natural vanadinite for $\mathrm{Cl}$. Quantitative corrections were performed using the ZAF method. Although careful analysis was performed to determine the presence of halogen, carbon, and sulfur, they were not detected, except only for a small amount of chlorine. Other oxide components such as $\mathrm{Al}_{2} \mathrm{O}_{3}, \mathrm{TiO}_{2}, \mathrm{FeO}, \mathrm{MgO}, \mathrm{MnO}, \mathrm{Na}_{2} \mathrm{O}$, and $\mathrm{K}_{2} \mathrm{O}$ were confirmed to be less than the detection limit of $0.1 \mathrm{wt} \%$. As shown in Table 1 , if we subtract the total $\mathrm{wt} \%$ of the detected constituents from 100 and regard the difference as the $\mathrm{wt} \%$ of water, the chemical composition of the mineral is almost identical to $\mathrm{Ca}_{6} \mathrm{Si}_{3} \mathrm{O}_{11}(\mathrm{OH})_{2}$ or $3\left(\mathrm{Ca}_{2} \mathrm{SiO}_{4}\right) \cdot \mathrm{H}_{2} \mathrm{O}$ : only a very small amount of chlorine substitutes $(\mathrm{OH})$.

\section{X-RAY DIFFRACTION DATA}

The X-ray powder diffraction pattern of dellaite was obtained using a Gandolfi camera with a diameter of 114.6 $\mathrm{mm}$ and $\mathrm{Ni}$-filtered $\mathrm{Cu} K \alpha$ radiation. A fragment of the crystals of dellaite having the approximate dimension of $100 \times 70 \times 30 \mu \mathrm{m}$ was picked up from the thin section, which was analyzed for chemical composition, under a binocular microscope with an effort to reduce the contamination of associate minerals such as calcite and clintonite, and was put on the edge of a glass fiber $(10 \mu \mathrm{m}$ in diameter). The powder X-ray diffraction patterns of the fragment with and without a standard $\mathrm{Si}$-material (NBS, \#640b) placed on its surface were recorded on imaging plates and processed using a Fuji BAS-2500 bio-imaging analyzer and a computer program by Nakamuta (1999). The powder X-ray diffraction data of dellaite are given in Table 2. The unit cell parameters were refined from the powder X-ray diffraction data on the standard $\mathrm{Si}$-material using a computer program by Toraya (1993): $a=6.815(4)$, $b=6.937(3)$, and $c=12.890(6) \AA ; \alpha=90.71(4), \beta=$ 97.68(4), $\gamma=98.20(4)^{\circ}$, and $V=597.4(5) \AA^{3}$. The diffraction data of $\mathrm{Ca}_{6}\left(\mathrm{Si}_{2} \mathrm{O}_{7}\right)\left(\mathrm{SiO}_{4}\right)(\mathrm{OH})_{2}$, the synthetic equivalent of dellaite (ICDD\#29-376), and those simulated on the basis of its crystal structure (Safronov et al., 1981) are given for comparison. As shown in Table 2, the powder pattern of the mineral is identical to that of the synthetic material.

\section{OPTICAL DATA}

The mineral is transparent and colorless under the microscope, it is optically biaxial with low birefringence. Optical indices were measured by the oil immersion method, with a calibration procedure by using an Abbe refractometer. The indices are $\alpha=1.655$ and $\gamma=1.664$. The twiceoptical axial angle is large $\left(>70^{\circ}\right)$ and negative.

Unfortunately, at present, there is inconsistency between the optical data of the material, synthesized by Roy (1958) and those of dellaites described by Agrell (1965) and obtained from the Akagane mine. Roy (1958) reported that the twice-optical angle is biaxial negative and smaller than $30^{\circ}$. The dellaite found at Kilchoan has a negative $2 \mathrm{~V}$ of $65^{\circ}$. Thus, our data are close to those of Kilchoan dellaite, but significantly different from those of the synthetic dellaite.

As demonstrated in Figure 2C, some dellaite grains exhibit polysynthetic twinning. Although the crystallographic orientation of this twinning is unclear due to a lack of single-crystal studies, the angle between $z$ ' and the trace of the twinning plane is up to $25^{\circ}$.

\section{GENESIS}

Roy (1958) synthesized the phase Y by using the hydrothermal quenching technique, and confirmed that it is stable up to $800{ }^{\circ} \mathrm{C}$. On the basis on field evidence, Agrell (1965) has suggested that dellaite (and calcite) is the hydration product of spurrite, $\mathrm{Ca}_{5}\left(\mathrm{SiO}_{2}\right)_{2}\left(\mathrm{CO}_{3}\right)$. At the Akagane mine, the mineral occurs in the bicchulite-vesuvianite skarn, which appears to be a hydration product of gehlenite (Bunno et al., 1982). As at Kilchoan, dellaite occurs at Akagane as veins or irregular patches with calcite, and it is highly possible that the dellaite found at Akagane is a later-stage hydration product of pre-existing skarn mineral(s) under a silica-deficient environment.

\section{ACKNOWLEDGMENTS}

We thank Dr. Kohei Sato for his help during the field survey, Ms. Masako Shigeoka for her assistance in EPMA 
Table 2. X-ray powder diffraction data of dellaite

\begin{tabular}{|c|c|c|c|c|c|c|c|c|c|c|c|c|c|c|c|c|c|c|c|}
\hline \multirow[b]{2}{*}{$h$} & \multirow[b]{2}{*}{$k$} & \multirow[b]{2}{*}{$l$} & \multicolumn{3}{|c|}{ Akagane* } & \multicolumn{2}{|c|}{ Syn. $^{\dagger}$} & \multicolumn{2}{|c|}{ Syn. ${ }^{\ddagger}$} & \multirow[b]{2}{*}{$h$} & \multirow[b]{2}{*}{$k$} & \multirow[b]{2}{*}{$l$} & \multicolumn{3}{|c|}{ Akagane* } & \multicolumn{2}{|c|}{ Syn. $^{\dagger}$} & \multicolumn{2}{|c|}{ Syn. ${ }^{\ddagger}$} \\
\hline & & & $I$ & $d_{\text {obs. }}$ & $d_{\text {calc. }}$ & $I$ & $d_{\text {obs. }}$ & $I_{\text {calc. }}$ & $d_{\text {calc. }}$ & & & & $I$ & $d_{\text {obs. }}$ & $d_{\text {calc. }}$ & $I$ & $d_{\text {obs. }}$ & $I_{\text {calc. }}$ & $d_{\text {calc. }}$ \\
\hline 0 & 1 & 0 & 9 & 6.84 & 6.86 & 11 & 6.84 & 11 & 6.86 & 0 & 0 & 5 & 51 & 2.55 & 2.55 & 80 & 2.551 & 79 & 2.56 \\
\hline 1 & 0 & 0 & 9 & 6.66 & 6.68 & 16 & 6.66 & 14 & 6.69 & -2 & 0 & 4 & 10 & 2.48 & 2.48 & 16 & 2.483 & 9 & 2.49 \\
\hline 0 & -1 & 1 & & & 6.13 & 3 & 6.11 & 1 & 6.12 & -2 & 2 & 2 & 12 & 2.47 & 2.47 & & & 12 & 2.47 \\
\hline 0 & 1 & 1 & & & 5.97 & 2 & 5.95 & 1 & 5.97 & 2 & 0 & 3 & & & 2.47 & 25 & 2.468 & 4 & 2.48 \\
\hline 1 & 0 & 1 & 6 & 5.60 & 5.61 & 16 & 5.59 & 11 & 5.63 & 2 & -1 & 3 & 12 & 2.42 & 2.42 & 20 & 2.421 & 13 & 2.43 \\
\hline-1 & 1 & 0 & 8 & 5.16 & 5.18 & 9 & 5.16 & 7 & 5.18 & -2 & 1 & 4 & 4 & 2.40 & 2.40 & 9 & 2.399 & 6 & 2.40 \\
\hline-1 & 0 & 2 & & & 4.97 & & & 7 & 4.97 & 0 & 1 & 5 & 4 & 2.37 & 2.37 & 14 & 2.368 & 4 & 2.37 \\
\hline-1 & 1 & 1 & 12 & 4.95 & 4.94 & 13 & 4.95 & 3 & 4.94 & 2 & -2 & 2 & & & 2.33 & 7 & 2.332 & 0 & 2.34 \\
\hline 0 & -1 & 2 & 7 & 4.76 & 4.75 & 9 & 4.73 & 8 & 4.75 & 1 & 1 & -5 & 5 & 2.33 & 2.33 & & & 5 & 2.34 \\
\hline 1 & -1 & 1 & 5 & 4.67 & 4.67 & 11 & 4.65 & 8 & 4.67 & 1 & 2 & 3 & & & 2.30 & 5 & 2.299 & 11 & 2.30 \\
\hline 0 & 1 & 2 & 10 & 4.60 & 4.60 & 20 & 4.59 & 17 & 4.61 & 0 & 3 & 0 & 38 & 2.29 & 2.29 & 30 & 2.287 & 33 & 2.29 \\
\hline-1 & -1 & 1 & & & 4.38 & 4 & 4.37 & 2 & 4.38 & 1 & 0 & 5 & & & 2.28 & & & 9 & 2.29 \\
\hline 1 & 0 & 2 & & & 4.33 & 9 & 4.32 & 7 & 4.34 & -2 & -1 & 4 & 14 & 2.27 & 2.28 & 25 & 2.275 & 17 & 2.28 \\
\hline 0 & 0 & 3 & 6 & 4.25 & 4.26 & 20 & 4.24 & 16 & 4.26 & -1 & 3 & 0 & & & 2.27 & 16 & 2.266 & 16 & 2.27 \\
\hline-1 & 1 & 2 & & & 4.19 & 4 & 4.17 & 3 & 4.19 & -3 & 0 & 1 & & & 2.25 & & & 10 & 2.25 \\
\hline 1 & 1 & 1 & & & 4.08 & 4 & 4.08 & 3 & 4.09 & -2 & -2 & 1 & 29 & 2.24 & 2.25 & 20 & 2.247 & 6 & 2.25 \\
\hline 1 & -1 & 2 & & & 3.87 & 16 & 3.865 & 1 & 3.88 & -1 & 3 & 1 & & & 2.24 & 20 & 2.237 & 1 & 2.24 \\
\hline-1 & 0 & 3 & & & 3.84 & 5 & 3.830 & 3 & 3.84 & 2 & 2 & 0 & & & 2.24 & & & 10 & 2.24 \\
\hline 0 & -1 & 3 & & & 3.67 & 2 & 3.662 & 1 & 3.67 & -3 & 1 & 1 & 8 & 2.23 & 2.23 & 13 & 2.230 & 8 & 2.23 \\
\hline 0 & 1 & 3 & & & 3.57 & 5 & 3.559 & 4 & 3.57 & 1 & -1 & 5 & & & 2.22 & 9 & 2.217 & 7 & 2.22 \\
\hline 1 & 1 & 2 & & & 3.48 & 4 & 3.481 & 5 & 3.49 & -3 & 0 & 2 & 2 & 2.20 & 2.20 & 7 & 2.198 & 5 & 2.20 \\
\hline 0 & 2 & 0 & 23 & 3.43 & 3.43 & & & 20 & 3.43 & 3 & -1 & -2 & 12 & 2.18 & 2.18 & & & 12 & 2.18 \\
\hline-1 & 1 & 3 & & & 3.43 & 18 & 3.426 & 1 & 3.43 & -2 & 0 & 5 & & & 2.18 & 18 & 2.178 & 5 & 2.18 \\
\hline 1 & 0 & 3 & & & 3.39 & 14 & 3.380 & 12 & 3.39 & 3 & 0 & 1 & & & 2.15 & 15 & 2.144 & 8 & 2.15 \\
\hline-2 & 0 & 1 & & & 3.35 & & & 11 & 3.35 & 3 & -1 & 1 & 22 & 2.14 & 2.14 & 18 & 2.137 & 8 & 2.14 \\
\hline 2 & 0 & 0 & 30 & 3.34 & 3.34 & 30 & 3.342 & 9 & 3.35 & 0 & 3 & 2 & & & 2.13 & 11 & 2.130 & 6 & 2.13 \\
\hline 0 & -2 & 1 & & & 3.34 & & & 10 & 3.34 & 2 & -2 & -4 & 4 & 2.10 & 2.10 & & & 4 & 2.10 \\
\hline 0 & 2 & 1 & 16 & 3.28 & 3.29 & 11 & 3.284 & 11 & 3.29 & -3 & 0 & 3 & & & 2.09 & 5 & 2.094 & 0 & 2.10 \\
\hline-1 & -1 & 3 & & & 3.27 & 13 & 3.267 & 11 & 3.27 & 0 & -2 & 5 & 2 & 2.08 & 2.08 & 5 & 2.080 & 5 & 2.08 \\
\hline-1 & 2 & 0 & 24 & 3.25 & 3.25 & 20 & 3.247 & 25 & 3.25 & 1 & 2 & 4 & & & 2.05 & 7 & 2.054 & 5 & 2.06 \\
\hline-2 & 1 & 0 & 15 & 3.19 & 3.19 & & & 14 & 3.20 & 2 & 2 & 2 & & & 2.04 & 5 & 2.042 & 3 & 2.04 \\
\hline 0 & 0 & 4 & & & 3.19 & 20 & 3.187 & 4 & 3.20 & 3 & 0 & 2 & 5 & 2.02 & 2.02 & & & 4 & 2.02 \\
\hline-2 & 0 & 2 & 4 & 3.14 & 3.14 & 7 & 3.142 & 5 & 3.15 & -3 & -1 & 2 & & & 2.02 & 11 & 2.018 & 0 & 2.02 \\
\hline 0 & -2 & 2 & 53 & 3.07 & 3.06 & 50 & 3.059 & 63 & 3.06 & 2 & 1 & 4 & 7 & 2.00 & 2.00 & 30 & 2.000 & 23 & 2.00 \\
\hline 2 & -1 & 1 & 9 & 3.02 & 3.02 & 14 & 3.020 & 9 & 3.02 & -1 & -2 & 5 & & & 2.00 & & & 8 & 2.00 \\
\hline-2 & 1 & 2 & & & 3.00 & 14 & 2.994 & 8 & 3.00 & 0 & 3 & 3 & 8 & 1.991 & 1.988 & 13 & 1.988 & 4 & 1.989 \\
\hline 0 & 2 & 2 & 38 & 2.99 & 2.98 & 45 & 2.982 & 52 & 2.98 & 2 & -3 & 1 & & & 1.988 & & & 5 & 1.988 \\
\hline 1 & 2 & 0 & 34 & 2.89 & 2.89 & 35 & 2.886 & 35 & 2.89 & -2 & 3 & 2 & 4 & 1.966 & 1.966 & 10 & 1.964 & 5 & 1.965 \\
\hline-2 & -1 & 1 & 44 & 2.86 & 2.87 & 50 & 2.856 & 23 & 2.86 & -3 & 0 & 4 & 3 & 1.958 & 1.957 & 13 & 1.957 & 5 & 1.958 \\
\hline 1 & -2 & 2 & & & 2.86 & & & 18 & 2.86 & -2 & -2 & 4 & & & 1.937 & 20 & 1.935 & 1 & 1.937 \\
\hline 2 & 1 & 0 & & & 2.85 & 8 & 2.846 & 6 & 2.85 & 2 & -2 & 4 & 27 & 1.937 & 1.935 & & & 14 & 1.938 \\
\hline-1 & 1 & 4 & & & 2.82 & 100 & 2.821 & 5 & 2.83 & -2 & 0 & 6 & 10 & 1.918 & 1.918 & & & 6 & 1.919 \\
\hline 2 & 0 & -3 & 100 & 2.82 & 2.82 & & & 100 & 2.82 & 1 & -1 & 6 & & & 1.914 & 9 & 1.913 & 4 & 1.917 \\
\hline 2 & 0 & 2 & & & 2.81 & 70 & 2.806 & 53 & 2.81 & 2 & 0 & 5 & & & 1.907 & 9 & 1.907 & 4 & 1.912 \\
\hline 2 & -1 & 2 & 33 & 2.73 & 2.73 & 45 & 2.730 & 36 & 2.74 & -2 & 2 & 5 & 8 & 1.898 & 1.898 & 7 & 1.898 & 6 & 1.898 \\
\hline 0 & -2 & 3 & 28 & 2.71 & 2.71 & 30 & 2.713 & 29 & 2.71 & 3 & -1 & 3 & 5 & 1.873 & 1.871 & 9 & 1.869 & 1 & 1.875 \\
\hline-2 & 1 & 3 & & & 2.71 & & & 11 & 2.71 & 3 & 1 & 2 & & & 1.866 & & & 5 & 1.870 \\
\hline 0 & 2 & 3 & 31 & 2.63 & 2.63 & & & 35 & 2.63 & 1 & 2 & 5 & & & 1.836 & 13 & 1.836 & 15 & 1.839 \\
\hline-1 & 2 & 3 & & & 2.63 & 40 & 2.629 & 6 & 2.63 & -2 & -1 & 6 & 9 & 1.823 & 1.821 & 11 & 1.821 & 12 & 1.822 \\
\hline-2 & 2 & 0 & 16 & 2.59 & 2.59 & 18 & 2.587 & 19 & 2.59 & -3 & 0 & 5 & & & 1.805 & 3 & 1.803 & 0 & 1.806 \\
\hline-2 & 2 & 1 & & & 2.58 & 9 & 2.578 & 7 & 2.58 & & & & & & & & & & \\
\hline
\end{tabular}

" $a=6.815(4), b=6.937(3), c=12.890(6) \AA, \alpha=90.71(4), \beta=97.68(4), \gamma=98.20(4)^{\circ}, V=597.4(5) \AA^{3}$, present study.

${ }^{\dagger}$ Synthetic $\mathrm{Ca}_{6}\left(\mathrm{Si}_{2} \mathrm{O}_{7}\right)\left(\mathrm{SiO}_{4}\right)(\mathrm{OH})_{2}, a=6.815, b=6.934, c=12.882 \AA, \alpha=90.67, \beta=97.70, \gamma=98.14^{\circ}, \mathrm{ICDD} \# 29-376$.

${ }^{\ddagger}$ Simulated XRD data based on the crystal structure analysis of synthetic $\mathrm{Ca}_{6}\left(\mathrm{Si}_{2} \mathrm{O}_{7}\right)\left(\mathrm{SiO}_{4}\right)(\mathrm{OH})_{2} ; a=6.825(2), b=6.931(1), c=12.907(5)$ $\AA, \alpha=90.68(2), \beta=97.57(3), \gamma=98.18(2)^{\circ}, V=596.6(7) \AA^{3}$, Safronov et al. (1981). 
analysis, and Mr. Fumihiko Matsuyama for providing references.

\section{REFERENCES}

Agrell, S.O. (1965) Polythermal metamorphism of limestones at Kilchoan, Ardnamurchan. Mineralogical Magazine, 34, 1-15.

Bunno, M., Shimazaki, H. and Sato, K. (1982) Occurrence and genesis of bicchulite and tilleyite skarns at the Sakae adit, the Akagane mine, Iwate Prefecture. Mining Geology, 32, 141-150 (in Japanese with English abstract).

Excalibur Mineral Corporation (2005) Photographic Guide to Mineral Species. CD-ROM, New York.

Glasser, L.D. and Roy, D.M. (1959) Further studies on $6 \mathrm{CaO}$ $3 \mathrm{SiO}_{2} \cdot \mathrm{H}_{2} \mathrm{O}$. American Mineralogist, 44, 447-451.

Ishiyama, D. (2005) World skarn deposits: Skarns of Japan. One Hundredth Anniversary Volume (Hedenquist, J.W., Thompson, J.F.H., Goldfarb, R.J. and Richards, J.P. Eds.). Appendix, CD-ROM, Society of Economic Geology, Colorado, USA.
Nakamuta, Y. (1999) Precise analysis of a very small mineral by an X-ray diffraction method. Journal of Mineralogical Society of Japan, 28, 117-121 (in Japanese with English abstract).

Roy, D.M. (1958) Studies in the system $\mathrm{CaO}-\mathrm{Al}_{2} \mathrm{O}_{3}-\mathrm{SiO}_{2}-\mathrm{H}_{2} \mathrm{O}$ IV; Phase equilibria in the high-lime portion of the system $\mathrm{CaO}-$ $\mathrm{SiO}_{2}-\mathrm{H}_{2} \mathrm{O}$. American Mineralogist, 43, 1009-1028.

Safronov, A.N., Nevsky, N.N., Ilyukhin, V.V. and Belov, N.V. (1981) A refinement of the crystal structure of a cement phase, $\gamma-\mathrm{C}_{6} \mathrm{~S}_{3} \mathrm{H}$. Doklady Akademii Nauk SSSR, 256, 13871389.

Toraya, H. (1993) The determination of unit-cell parameters from Bragg reflection data using a standard reference material but without a calibration curve. Journal of Applied Crystallography, 26, 583-590.

Manuscript received February 14, 2008

Manuscript accepted June 10, 2008

Manuscript handled by Kazumasa Sugiyama 